\author{
Шкільник Богдан Стефанович, \\ аспірант кафедри методики музичного виховання \\ й диригування Дрогобицького державного \\ педагогічного університету імені Івана Франка \\ bogdan.shkilnik@ukr.net \\ ORCID: 0000-0002-2689-3834
}

\title{
ДО ПИТАННЯ ЕВОЛЮЦІЇ ЖАНРУ ХОРОВОЇ ОБРОБКИ ДУХОВНОЇ ПІСНІ В ТВОРЧОСТІ УКРАЇНСЬКИХ КОМПОЗИТОРІВ (90-ті рр. ХІХ - 40-ві рр. ХХ ст.)
}

Мета роботи полягає в тому, щоб піддати джерелознавчо-музикознавчому аналізу жанр хорової обробки духовних пісень XVII - XIX ст., який українські композитори започаткували у 90-х роках XIX ст. та активно розвивали, щонайменше, до початку 40-х років XX ст. Методологія. У процесі дослідження використано джерелознавчий, історичний, музично-теоретичний методи дослідження. Зазначений методологічний підхід дозволяє провести комплексний музично-джерелознавчий аналіз розвитку жанру. Наукова новизна. У результаті проведеної дослідницької роботи вдалося встановити, що жанр хорової обробки духовної пісні українськими композиторами тільки починає бути предметом уваги сучасних музикознавців. Завдяки проведеній джерелознавчобібліографічній роботі вдалося виявити десятки партитур українських композиторів із обробками духовних пісень. Встановлено також, що чимало хорових партитур опубліковано в авторських збірниках ще за час діяльності композиторів (О. Нижанківський, В. Матюк, К. Стеценко, М. Гайворонський, С. Людкевич, В. Барвінський та ін.). Висновки. Творчий процес над хоровими обробками українських духовних пісень за зазначений період часу можна розділити на два етапи (від поч. 90-х років ХІХ ст. до приблизно 1910-х років та від 1910-тих років до середини 40-х років XX ст.). Кожен із них вирізняється своєю специфікою, творчими оригінальними методами, якими послуговувалися українські композитори. Внаслідок проведеного музично-джерелознавчого та текстологічного аналізу з'ясовано, що більшість хорових обробок написано на тексти пісень почаївського «Богогласника» (17901791), його перевидань та редакцій у XIX ст. Чимало музично-поетичних текстів для хорового аранжування вибрано зі збірника П. Демуцького «Ліра та її мотиви» (К., 1903) та безпосередньо з пісенного фольклору.

Ключові слова: хорова партитура, духовна пісня, українські композитори, джерелознавчі студії, «Богогласник».

Шкильнык Богдан Стефанович, аспирант кафедры методики музикального воспитания и дирижирования Дрогобичского государственного педагогического университета имени Ивана Франко

К вопросу эволюции хоровой обработки духовной песни в творчестве украинских композиторов (90-е гг. XIX в. - 40-вые гг. XX в.)

Цель статьи состоит в том, чтобы провести источниковедческо-музыковедческий анализ жанра хоровой обработки духовных песен XVII - XIX вв., который украинские композиторы начали создавать в 90-х годах XIX в. и активно развивали до начала 40-х годов. Методология. В процессе исследования использованы источниковедческий, исторический, музыкально-теоретический методы исследования. Этот методологический подход позволяет провести комплексный музыкально-источниковедческий анализ жанра. Научная новизна. В результате проведенной исследовательской работы удалось установить, что жанр хоровой обработки духовной песни украинских композиторов только начинает быть предметом внимания современных музыковедов. Благодаря проведенной источниковедческо-библиографической работе удалось обнаружить десятки партитур украинских композиторов с обработками духовных песен. Многие хоровые партитуры опубликовано в авторских сборниках за время деятельности композиторов (О. Нижанковский, В. Матюк, К. Стеценко, М. Гайворонский, С. Людкевич, В. Барвинский и др.). Выводы. Творческий процесс над хоровыми обработками украинских духовных песен за обозначенный период времени можно разделить на два этапа (от нач. 90-х гг. XIX в. - примерно 1910-е гг. и от 1910х гг. до средины 40-х гг. XX в.). Каждый из них отличается своей спецификой, творческими оригинальными методами, которыми пользовались украинские композиторы. Установлено, что большинство хоровых обработок написано на тексты песен почаевского «Богогласник» (1790-1791), его переизданий и редакций ХІХ в. Многие музыкально-поэтические тексты для хоровых аранжировок выбрано из сборника П. Демуцкого «Лира и ее мотивы» (К., 1903) и непосредственно с песенного фольклора.

Ключевые слова: хоровая партитура, духовная песня, украинские композиторы, источниковедческие студии, «Богогласник». Ivan Franko

Shkil'nyk Bohdan, Postgraduate student, Institute of Musical Art, Drohobych State Pedagogical University named after

Evolution of Genre of Choral arrangements of Sacred Song in the creativity of Ukrainian composers (the end XIX - beginning XXI)

The Purpose of Article. The objective of the research concerns the subjection to the analysis of the genre of choral arrangements of the sacred songs of the XVII-XIXIX centuries in the interpretation of Ukrainian composers whose creativity

СШкільник Б. С., 2019 
belongs to the period from the end of the XIX to the middle of the XX century. Methodology. The methodology and research approaches in the process of research the following methods have been used: source study, historical and musical-theoretical. Scientific Novelty. As a result of the study, the author managed to clear out the fact that the genre of choral arrangements of the sacred song by Ukrainian composers has only begun to be an object of attention to modern musicologists. Due to the conducted source-study and bibliographical work the researcher was a success to discover dozens of score with arrangements of sacred songs by Ukrainian process is the fact that many of choral score were published in collections of work of various authors (O. Nyzankivs 'kyi, V. Matjuk, K. Stecenko, M. Hajvorons 'kyi, S. Liudkevych, V. Barvins 'kyi and other). Conclusions. The creative process of the choral processing of Ukrainian spiritual songs for the given period can be divided into two stages (from the beginning of the 90s of the 19th century until about 1910s and from the 1910s to the mid-40s of the 20th century). Each of them is distinguished by its specifics, creative, original methods used by Ukrainian composers. As a result of the conducted musicalsource-study and textual analysis, it was clarified that most choral arrangements are written on the lyrics of the Pochaiv "Bohohlasnyk" (1790 - 1791), its reprints and editions in the XIX century. Many musical and poetic texts for choral arrangements are drawn from the collection of P. Demuts'ky "Lira and her motives" (K., 1903) and directly from the folkloric songbook.

Key words: choral score, sacred song, Ukrainian composers, source-study, "Bohohlasnyk."

Актуальність теми дослідження. Українська духовна пісня пройшла тривалий шлях розвитку від зародження на межі XVI-XVII ст. до появи василіянської духовнопісенної творчості кін. XIX - першої половини XX ст. Але тільки наприкінці XIX ст. з'являються перші обробки духовних пісень галицьких та наддніпрянських композиторів. Їхня хорова спадщина мало вивчена, частково введена до наукового обігу, у концертну практику тощо.

Аналіз останніх досліджень і публікацій. Духовні пісні в обробці українських композиторів викликають помітне наукове зацікавлення від початку XXI ст., хоча перші спроби оцінки цих партитур з'явилися ще наприкінці XIX - у першій половині XX ст. Наприклад, I. Франко в статті «Наші коляди» (1889) відгукнувся на появу збірника О. Нижанківського, в якому було опубліковано хорові обробки різдвяних пісень композитора. Вчений писав: «... вийшла 3 друку гарна партитура, обнімаюча 20 найпопулярніших коляд церковних, підложених під ноти на чотири голоси мужеські. Гармонізації доконав i видав п[ан] Остап Нижанківський. Користаю 3 нагоди сього видання і надходячих свят Рождества Христового, щоб висказати кілька уваг о наших піснях церковних взагалі, а особливо о колядах» $[9,7]$.

У 1938 р. з'явилося друком ще одне вартісне видання - збірник хорових обробок пісень «Богогласника» М. Гайворонського. Він був прихильно оцінений С. Людкевичем та В. Витвицьким, музикознавчо-критичні замітки яких опубліковано на сторінках львівського часопису «Діло».

У радянські часи оцінкою жанру хорової обробки духовної пісні майже ніхто не цікався. Чи не вперше це зробив відомий музикознавець М. Гордійчук у монографії про М. Лисенка, доповнивши третє перевидання невеличким додатковим текстом про духовну музику композитора. У ньому знайшлося місце для побіжної оцінки його хорової обробки барокової пісні «Пречиста Діво Мати Руського краю» та канту «Крестним древом» $[1,211]$.

У добу Незалежності України до хорових обробок виявили зацікавлення М. Юрченко, О. Письменна, О. Цибух-Петришин, Г. Медведик, Ю. Медведик та ін. Нещодавно з'явилася стаття М. Юрченка, який вказав на те, що «Обробки релігійних кантів є цікавим і малодослідженим жанром в історії української музики» $[10,45]$. Немає сумніву і в тому, що «Хорові обробки українських релігійних кантів становлять цікаву сторінку в історії вітчизняної хорової музики»[10, 45]. На завершення короткого огляду вибраних публікацій, звернімо увагу на те, що й у статті Г. Медведик та Ю. Медведика мовиться: «Попри велику кількість різноманітних обробок, ці тексти не часто стають предметом спеціальної уваги музикознавців» [4, 233].

Мета цього дослідження полягає в тому, щоб здійснити загальний аналіз розвитку жанру хорової обробки духовної пісні у творчості українських композиторів від 90-х років ХІХ до 40-х років XX ст., дати оцінку вибраним партитурам.

Виклад основного матеріалу. На межі XIX-XX ст. українські композитори-романтики звернулися до духовної пісні з метою іiі популяризації вже не тільки у формі одноголосого, кантового (триголосого) чи народного гуртового співу (приміром, під час різноманітних хресних ходів), але й у формі спеціальної хорової обробки для виконання професійними або аматорськими колективами. Насамперед їх зацікавили духовнопісенні пісенні тексти «Богогласника» (Почаїв, 1790-1791), який нещодавно перевидано [11].

Аналізуючи збережені тексти партитур, можна дійти висновку, що розвиток жанру за понад піввіковий період пройшов два етапи. Зокрема, ранній етап припадає на 90-ті pp. XIX - перше десятиліття XX ст. Він знаменний тим, що упродовж творчого процесу майже одночасно було залучено композиторські сили митців Галичини та Наддніпрянщини. Першим, хто цілеспрямовано взявся за опрацювання духовних пісень у хоровому аранжуванні, був галицький композитор о. Остап Нижанківський, талановитий 
послідовник лисенківських традицій у тогочасній музичній культурі та музичній фольклористиці. Його хорові обробки різдвяних пісень («Коляди Остапа Нижанківського», Львів, 1889) переважно здійснені завдяки використанню богогласникових текстів. Невдовзі й М. Лисенко, як зазначалося, створив дві обробки (вперше одну з них надруковано у 1936 р. за ред. В. Барвінського).

До збірника хорових обробок О. Нижанківського увійшло 20 партитур, в основі яких лежать тексти різдвяних пісень, опублікованих у почаївському «Богогласнику». Їх нещодавно проаналізовано О. Письменною та О. Цибух-Петришин, які констатують: «... загалом в обробках колядок О. Нижанківського домінує гармонічне колоритування народної мелодії, в якій однією 3 характерних особливостей можна назвати барвисті звукокомплекси, що досягаються альтерованими змінами в акордовій побудові, хроматичними ходами по неакордових альтерованих звуках, переважно прохідних та допоміжних» [6; 172-173]. У контексті дослідження історії розвитку жанру хорової обробки української духовної пісні цей збірник має важливе значення, оскільки це було перше видання, до того ж авторське, редаговане композитором.

На ранньому етапі становлення жанру до обробок духовних пісень, теж здебільшого 3 «Богогласника», зверталися греко-католицький священик В. Матюк, відомий регент хору Київської Духовної Академії В. Петрушевський, композитор-аматор з Холмщини (тепер - Північно-Східна Польща) О. Вітошинський, який першим з-поміж західноукраїнських композиторів-аматорів уклав дві збірки власних хорових партитур з обробок пісень «Богогласника».

Обробки духовних пісень у зазначений період композитори створювали не тільки для концертного виконання, часткового урізноманітнення літургійної практики, але й для забезпечення музичнорелігійних потреб українського шкільництва. До цієї справи долучилися О. Нижанківський, В. Матюк, А. Вахнянин, а у 20-х роках - Микола Колесса та ін. композитори.

Велику роль у популяризації хорових обробок духовних пісень у ці два десятиліття відіграли хорові товариства «Боян» та хористи Київської Духовної Академії. На аматорському рівні хорові обробки духовних пісень популяризували численні церковні хори, міські та сільські колективи, серед яких особливий слід в історії залишив Охматівський народний хор під орудою відомого пропагандиста духовної пісні (псальми) Порфирія Демуцького, автора унікальної фольклористичної праці «Ліра та ії мотиви» (Київ, 1903). Музично-поетичні тексти псальм цього «Лірницького Богогласник» стали цінним джерельним матеріалом для тогочасних українських композиторів Наддніпрянщини, про що пише у своїй джерелознавчій-текстологічній розвідці Ю. Медведик [3, 79-90].

Приблизно з 10-х років XX ст. розпочинається зрілий етап розвитку жанру, який тривав до середини століття. Він найбільш плідний. У цей час до текстів духовних пісень зверталися композитори, що переважно походили з Наддніпрянщини, Галичини, меншою мірою Волині, Слобожанщини та Закарпаття (О. Кошиць, К. Стеценко, М. Леонтович, С. Людкевич, В. Ступницький, М. Гайворонський, П. Щуровська-Росіневич, В. Барвінський та ін.).

За заначений період стабілізуються шляхи розвитку жанру обробки духовної пісні у різних сферах церковного життя, освіти та культурно-просвітницької діяльності. Наприклад, О. Кошиць популяризував духовні пісні (канти), переважно власного аранжування, у студентському хоровому колективі Київського університету ім. св. Володимира, згодом - із хоровою капелою в Україні та світі. Натомість у Галичині, на Волині та Закарпатті практика творення хорових обробок духовних пісень насамперед отримувала свою популяризацію через церковне життя, численні хорові товариства та шкільництво. Н. Калуцька, дослідниця хорової спадщини О. Кошиця, звернула увагу на те, що О. Кошиць переважно послуговувався музичнопоетичними текстами, які добрив для власних хорових обробок з фольклорного середовища, використовував записи П. Демуцького. Слушний ії висновок про те, що «О. Кошиць створив низку власних циклів-добірок аранжувань, де риси драматургії відкривали можливості використання їх як окремого хорового циклу» [2, 136]. Натомість С. Салій акцентував увагу на тематичній палітрі текстів духовних пісень в обробці О. Кошиця, який «... вирізняв 3 них канти, зауважуючи їхню оригінальність («Вижду Тя на хресті роспята», «На ріках сідоком») і псальми («Свята Варвара», «О страстях Христових», «Ангелу хранителю»). Псальми створюють враження архаїчності, в них виявлена давня епічна традиція. У псальмах досить виразно простежується модальна ладова організація та лінеарна основа, що зберігає відгомін знаменного розспіву, хоча вагомо означені й риси куплетних структур та варіаційні зв'язки між розділами» $[8,59]$.

Ще одним рідкісним явищем у жанрі обробки духовних пісень став цикл В. Барвінського «Пісні 3 Богогласника (для мішаного хору без супроводу), опублікований в «Українському видавництві» (КраківЛьвів) 1944 р. Збірник присвячено Митрополитові Андрею Шептицькому. Як відомо 26 квітня 1941 р. у Львові відбувся Архиєпархиальний Собор, в «Правилах» якого йдеться про потребу залучення до церковного співу текстів «Богогласника», обробок духовних пісень українських композиторів, незалежно від їх конфесійної приналежності [7, 9]. 
Унікальність збірника у тому, що вперше не на аматорському рівні (як це зробив О. Вітошинський) створено цикл обробок покаянних пісень «Богогласника». Це ж відзначає й Л. Назар: «У циклі «Пісень 3 Богогласника» (1944р. в.) композитор, спираючись на богогласницькі наспіви, оперує широкою шкалою засобів хорового письма: середньовічна мозаїчна техніка, мікро-фуга (викладена в перших 5 тт. пісні «Про Пилата»), принципи барокового концертуючого письма та кантового багатоголосся, поєднання різних типів поліфонії - контрастної, імітаційної, підголоскової, властиве $\mathrm{XX}$ ст. накладання хорових масивів, мінімалізм як прояв сакрального музичного мислення» $[5,11]$.

На завершення треба відзначити великий внесок у розвиток жанру хорової обробки духовної пісні о. Й. Кишакевича, автора знаменитої різдвяної пісні-колисанки «Спи, Ісусе, спи». Він же й здійснив їі обробку для хору.

Висновки. Духовна пісня, зародившись на межі XVI-XVII ст. пройшла у своій еволюції шлях від одноголосого музичного тексту до багатоголосого (кант), а на межі XIX -XX ст. - до спеціальної хорової обробки, яка поступово еволюціонувала у творчості українських композиторів та досягнула піку свого розвитку в 30-40-х pp. XX ст. Проте й сьогодні духовна пісня є об'єктом творчої уваги сучасних композиторів, які в жанрі хорової обробки, використовуючи сучасні засоби музичної виразності та стилістики, продовжують розвивати цей напрямок музичної творчості (М. Скорик, Г. Гаврилець, В. Степурко та ін.)

\section{Лimepamypa}

1. Архімович Л., Гордійчук М. М. Лисенко: життя і творчість. Київ: Музична Україна, 1992. 254 с.

2. Калуцька Н. Драматургічні аспекти аранжування обрядового фольклору (Канти і псалми О. Кошиця). Украӥнське музикознавство. 2000. Вип. 30. С. 129-137.

3. Медведик Ю. Лірницький «Богогласник» Порфирія Демуцького До 110-ліття виходу у світ збірника «Ліра та їі мотиви». Мистецтвознавство Украӥни. 2013. Вип. 13. С. 79-90.

4. . Медведик Г., Медведик Ю. Обробка барокової духовної пісні як сфера зацікавлень українських композиторів «нової школи» української церковної музики першої третини XX століття. Актуальні проблеми історії, теорії та практики художньої культури. 2011. Вип. XXVII. С. 232-239.

5. Назар Л. Стильові виміри творчості Василя Барвінського: автореф. дис. канд. мистецтвознавства 17.00.03. Львів, 2007. 20 с.

6. Письменна О., Цибух-Петришин О. Коляди та щедрівки в обробках західноукраїнських композиторів XIXXX століть. Записки наукового товариства Шевченка. Львів, 2009. Т. CCLVIII. С. 166-189.

7. Про церковний спів. Львів : УКУ, 2001. 10 с.

8. Салій С. Хорові обробки в творчості Олександра Кошиця. Молодь і ринок. 2010. № 5 (64). С. 57 - 60.

9. Франко І. Наші коляди. Зібрання творів у 50-ти томах. Київ: Наукова думка, 1982. С. 7 - 41. (24). $45-51$.

10. Юрченко М. Хорові обробки українських релігійних кантів на початку XX ст. Українська музика. 2017. Ч. 2

11. Rothe H., Medvedyk J. Bogoglasnik. Pesni blagogovejnyja (1790/1791). Eine Sammlung geistliche Lieder aus Ukraine. Herausgegeben von Hans Rothe in Zusammenarbeit mit Jurij Medvedyk. Band 1: Facsimile. Köln-Weimar-Wien: Böhlau Verlag, 2016.602 S.

\section{References}

1. Archimovych, L., Hordijchuk M. (1992). Mykola Lysenko: life and work. Kyiv: Muzychna Ukraina [in Ukrainian].

2. Kaluc'ka, H. (2000). Dramatic aspects of the arrangement of ceremonial folklore (kant's and psalm`s O. Koshyts'). Ukrainian musicology. Vol. 30, 129-137 [in Ukrainian].

3. Medvedyk, J. (2013). Lirnyc's «Bohohlasnyk» P. Demuts'ky (to 110 anniversary «Lira and her motives»). History of arts of Ukraine. Vol. 13, $79-90$ [in Ukrainian].

4. Medvedyk, H., Medvedyk, J. (2011). Arrangements of baroque Sacred song as a sphere of interest of Ukrainian composers of the «new school» of Ukrainian church music of the first third of the XX century. Topical problems of History, Theory and Practice of Artistic Culture. Vol. XXVII, 232-239 [in Ukrainian].

5. Nazar, L. (2007)- Stylistic measurement of Vasyl Barvinsky`s creation: abstract. L'viv, 20 [in Ukrainian].

6. About church singing (2001). L'viv, 10 [in Ukrainian].

7. Saliy, S. (2010). Choral arrangements in creativity by Olexandr Koshyts`. Youth and the market. Vol. № 5-6, 57-60.

8. Franko, I. (1982). Our carols. Collection of works in 50 volumes. Kyiv, 7-41.

9. Pys'menna, O., Tsybukh-Petryshyn, O. (2009). Christmas carols and hymns in the arrangements by Ukrainian composers of the $19^{\text {th }}$ and the first half of the $20^{\text {th }}$ centuries. Memoirs of the Shevchenko Scientific Society. Vol. CCLVIII, 166189 [in Ukrainian].

10. Yurchenko, M. (2017). Choral arrangements of Ukrainian religious kant's at the beginning of the $20^{\text {th }}$ century.Ukrainian music. Vol. 2 (24), 45-51 [in Ukrainian].

11. Rothe H., Medvedyk J. (2016). Bogoglasnik. Pesni blagogovejnyja (1790/1791). Eine Sammlung geistliche Lieder aus Ukraine. Herausgegeben von Hans Rothe in Zusammenarbeit mit Jurij Medvedyk. Band 1: Facsimile. Köln-Weimar-Wien: Böhlau Verlag, 602 S. [in German, in Ukrainian].

Стаття надійшла до редакиії 17.09.2019 p. 